\title{
Revitalizing Technical and Vocational Education Training for Poverty Eradication and Sustainable Development through Agricultural Education.
}

Ibrahim Hamza Alhaji

\section{Abstract}

The goal 1 of the Millennium Development Goals (MDGs) is to: Eradicate extreme poverty and hunger. Nigeria as a developing country with a population of 140 million people is battling with food insecurity, poverty and youth unemployment problems. This paper therefore focused on the contribution of a revitalized technical and vocational education and training with emphasis on agricultural education to improve the economic status of the country and welfare of the people, trigger entrepreneurship which would eventually lead to job creation. Issues pertaining to women empowerment, integrating technical and vocational education and training (TVET) in education curricula, agricultural education and the rural poor was discussed. The paper concludes that to solve the problem of widespread poverty, unemployment and national food deficit, priority should be given to revitalizing technical and vocational education and training with top priority given to a functional agricultural education. Six major recommendations were proffered.

\section{Introduction}

Nigeria is well blessed by nature. In addition to its vast crude oil deposits, Nigeria has vast expanse of land, water, forest resources, favorable climate and vibrant population. All these are veritable instruments for great agricultural potentials. Despite this advantage, the issue of food security and poverty are twin problems the government has over the 
years consistently try to solve. The goal 1 of the Millennium Development goals is to: Eradicate extreme poverty and hunger. The target is to "halve, between 1990 and 2015, the proportion of people whose income is less than $\$ 1$ a day; and half between 1990 and 2015 the proportion of people who suffer from hunger"(sachs, 2004).

With the above Millennium Development goal in mind, it has therefore become imperative for the Nigeria government to seek solution to the issue of food self-sufficiency within the broad context of poverty alleviation and youth employment in this Millennium. This the government can achieve by revitalizing technical and vocational education and training with emphasis on agricultural education programme for job creation and poverty alleviation in this millennium. It is against this backdrop that this paper seeks to highlight the relevance of TVET in the present dispensation, to actualize poverty eradication through agricultural education, and the role of agricultural education towards self-actualization or self employment for sustainable development.

\section{Revitalizing technical and vocational education and training in Nigeria}

Skill training enhances productivity and sustains competitiveness in the global economy. Worldwide countries are renewing efforts to promote technical and vocational education and training, this is because it is the only way to prepare young people for the world of work, which reaches out to the marginalized and excluded groups to engage them in income-generating livelihoods.

High unemployment has been leading to increasing poverty and serious social problems in Nigeria; coincidentally there has 
Revitalizing Technical and Vocational Education...

been a decline in TVET enrolments (EFA, 2000). Less than $1 \%$ of secondary education was oriented towards technical and vocational skills. Therefore there is the need to revitalized TVET as the best means to improve economic opportunities for the teaming youths of Nigeria. It is in recognition of this that government has gone into agreement with the UNESCO's section for technical and vocational education through the National Board for Technical Education (NBTE). Currently NBTE is implementing a project that aims to better equip large numbers of young Nigerians for the world of work. A cost sharing agreement was therefore signed in 2000, between UNESCO and Nigeria Federal Ministry of Education to revise the curricula for secondary technical colleges and post secondary polytechnics and established a new system of continuing technical staff development and training, but still yet the Nigeria government need to do more in view of the enormity of the problem.

\section{The concept of vocational education}

Vocational education is "education and training for work; it is an education where skills are taught for the purpose of gaining employment through exposure to practical experience for self-actualization. According to UNESCO (1973) as cited in Okorie (2001), vocational education is education designed to prepare skill workers for industries, Agriculture, commerce etc.

Vocational education can be regarded as experience gained directly or indirectly that enables one to participate in a socially useful occupation either in or out of school, at various levels and to be sufficiently equipped to become an intelligent creator of goods and services. The continued deterioration of the national economy is a clear signal to every Nigerian to try hard for a reliable and independent means of survival. This can only be realized through improved vocational training 
programmes with emphasis on functional agricultural education.

\section{Vocational education and the rural poor}

Technical and vocational education and training plays an essential role in improving the wellbeing of rural families and communities. It increases productivity, empowers individual to become self-reliant and stimulates entrepreneurship. Businesses are more willing to invest in a community with strong human resources. Skills development can therefore contribute to strengthening the social links of a community by promoting local employment, creativity and sustainable means of subsistence.

Since there is a strong link between poverty and rurality: In Nigeria over $70 \%$ of poor people live in rural areas where enrolment rates in all types of education are low, reducing poverty therefore will entails increasing rural educational opportunities as part of an overall development strategy, here TVET becomes a handy tool, as it can be both formal and informal. Such skill development of the rural poor must take into account

1. Skills to diversify the rural economy rather than reliance on agriculture alone

2. Equipping the people to add value to agriculture-based products

3. Training in basic literacy, numeracy and life skills should be an integral part of the whole program

4. The promotion of the growth and profitability of local traditional crafts and industries 
Revitalizing Technical and Vocational Education...

However statistic as cited by Biakpara (2004) reveals that agriculture contributes about $41 \%$ to GDP and remains the lead sector for providing income and employment for the rural poor people. According to him, it employs $90 \%$ of the rural poor, nearly $70 \%$ of the total labor force and provides $90 \%$ of non-oil export revenue. Therefore a functional agricultural education through a well designed vocational programme remains one of the major key to alleviating poverty among the rural poor for sustainable development.

\section{Technical and Vocational education for sustainable development}

Education in whatever form is aimed at modeling a child or the individual into a better person relevant to his immediate environment. Sustainable development cannot be achieved without education. Development is a process where an economy undergoes social and economic transformation leading to a rise in the standard of living, access to basic amenities for all through knowledge.

It is in recognition of the above concept of development that technical and vocational education and training for poverty alleviation should be given utmost priority by government, having in mind the future consequence and task ahead for sustainable development. The future prospect and success of the TVET would depend on the continuation and expansion of the existing training programmes and strengthening the existing cooperation both with national and international, as well as by starting non-formal training programmes for the unemployed and the community at large as part of the government poverty alleviation efforts toward sustain welfare of the people and development. 


\section{Women empowerment and Agricultural education}

Though TVET can be a decisive instrument in increasing opportunities for women to participate in the work force and to improve there living conditions and social status through agricultural education, gender disparities still persist in many countries including Nigeria. Efforts should therefore be geared towards ensuring equal access to and participation in TVET programmes for girls and women especially those who are marginalized. Women are responsible for half of the world's food production and between $60 \%$ and $80 \%$ of the food in most developing countries. Not only are women the mainstay of the agricultural food sector, labor force, and food systems, they are also largely responsible for post harvest activities. However, women's fundamental contribution is continually under-appreciated and under-supported, and is often adversely affected by prevailing economic policies and other development conditions. This situation must be given serious attention by government, since sustainable rural development through agriculture cannot be achieved without the full participation of women. Agricultural education is therefore a sure means through which gender equality and women empowerment can be achieve, as a greater number of the rural poor are made up of women and children.

\section{Integrating Skill Development in Education for All (EFA)}

Ensuring that all learning needs of young people and adults are met through equitable access to appropriate learning and life skills programmes is one of the six educations for all (EFA) goals established at the world education forum in Dakar 2000. So the provision of vocational skills training on 
Revitalizing Technical and Vocational Education...

agricultural education should therefore constitute an important component in national strategies if the EFA goal is to be achieved. But developing countries including Nigeria tend to concentrate on universal primary education and literacy, but do not pay sufficient attention to skill training for youths and adults, even though there are numerous initiatives focusing on providing education and training people from marginalized group. This in most case are often small in scale and are not always recognized as part of a comprehensive national education strategy. There is the need for government to urgently consider redesigning the curricula with emphasis on skill acquisition, especially agricultural education, if the government target of reducing or eradicating poverty by the year 2020 is to be achieved.

In 2003, existing skills training programmes for the disadvantage groups were reviewed, and policies and institutional environment were analyzed in four countries in Africa and Asia (Mali, Senegal, Laos and Nepal). The experience of these selected countries was shared with other developing countries at an inter-regional seminar held at the International Institute for education planning (Paris, 22-23 January 2004). Suggestion to a more comprehensive approach to EFA was discussed and all stakeholders to EFA are to implement some of the policies and strategies for efficient result and feed back.

Incorporating TVET in the EFA programme is a necessity in all developing countries because it advocates for flexible access to learning and training throughout life while down playing the shortcoming of the beneficiary in other to accommodate a larger group for sustainable development and improve/enhance productivity (Hamza, 2005). 


\section{Agricultural education and poverty eradication}

Agriculture is the main way of making a living either as pure subsistence farmers or with a little semi-commercial farming. Majority of these subsistence farmers are poor people faced with many constraints that keep them poor, such as lack of knowledge and skill, lack of information and knowledge about what to produce, and how to produce to earn more money.

One sector that can help attain the Millennium Development Goals (MDGs) is agriculture. Agricultural education has been recognized as an important instrument of social change that can foster development. The impact of agricultural education for poverty alleviation in the development of a nation cannot therefore be overemphasized if the attendant constraint to sustainable agriculture for national development is to be achieved. Literacy and access to basic education are the pre-requisite for any type of development. A functional agricultural education becomes a handy tool for poverty alleviation and sustainable development as majority of the target rural population already have basic knowledge of agricultural production. Providing agricultural education (modernizing agriculture) will eradicate poverty through first of all increased production thus ensuring that there is enough food for all people at all times. Secondly, farmer access to knowledge, improve seed, and other relevant information will lead them to produce more high value crops that sell well in the market. Income from sale of produce will help farmer access other household necessities, pay health and education costs and have extra to spare. More jobs will be created in agriculture and agriculture-related activities such as transportation, storage, processing, marketing, and so on. At 
Revitalizing Technical and Vocational Education...

the end of the day poverty will be eradicated as a result of; increase in income because of the rise in farm productivity, increase in the share of agriculture that can be marketed and the creation of many on-farm and off-farm jobs related to agriculture.

\section{Conclusion}

The ideal of sustainable development and poverty alleviation, although broad and tinged with ambiguity in its understanding and application, it is still palatable to everybody as it forms the bedrock of government socio-economic policies and programmes. For government to solve the problem of widespread poverty, national food deficits, and unemployment, technical and vocational education and training with emphasis on the right agricultural education should be given top priority.

The Nigerian government through her various poverty alleviation programmes has also undertaken several project to enhance technical and vocational education and training opportunities in the poor rural areas, but a lot still need to be done in the area of the target population, logistic and welfare packages for staffs involved so as to improve efficiency and result oriented programme in the no-distant future.

\section{Recommendation}

1. Government should provide strategy and implement plan for increasing TVET opportunities for people with disabilities.

2. TVET programmes should provide a world class skill and knowledge with opportunities for the indigenous people using available local materials and technology

3. Agricultural education should be incorporated at all levels of the educational curricula and adult education centers expanded and equipped properly. 
4. A flexible learning environment and frame work should be provided for the would-be beneficiaries

5. Government should focus on poverty eradication through a functional agricultural education while providing basic literacy.

6. Communities should be carried along in such a way that the TVET programme will be inclusive and sustainable.

\section{References:}

Biakpara, P.Y.(2004). Unpublished keynote address at the 49th meeting of the Association of Dean's of Agriculture in Nigerian Universities (ADAN). Education For All 2000 Assessment: Report of Nigeria by UNESCO.

Ibrahim H. (2005). Restructuring Agricultural Education for Nation Building and Sustainable Development. A paper presented at the $11^{\text {th }}$ Annual National Conference of the National Association of Curriculum Theorist, 19 - 23 September 2005.

International Institute for Education and Planning (IIEP) Newsletter, vol XXI, No 1, January - March 2004, pg10.

Sachs, J. D. (2004). Economics and Nutrition: How do they intersect? In Nutrition and Millennium Development Goals SCN News, Number 28, July, ISSN 1564 - 3743 